\title{
SANDFLY FAUNA (DIPTERA: PSYCHODIDAE) IN PARQUE DO SABIÁ COMPLEX, UBERLÂNDIA, MINAS GERAIS, BRAZIL
}

Elisângela de Azevedo Silva RODRIGUES(1), José Dilermando ANDRADE FILHO(2), Jean Ezequiel LIMONGI(1) \& Márcia Beatriz Cardoso de PAULA(1)

\begin{abstract}
SUMMARY
Between April 2003 and May 2009 phlebotomine sandflies were collected in Parque do Sabiá complex, Uberlândia municipality, Minas Gerais State, Brazil, using CDC and Shannon traps. The objective was to associate the sandfly species captured to the risk of the transmission of leishmaniasis in the municipality. The 126 captured specimens belonging to six species of phlebotomine, among which Lutzomyia (Psychodopygus) davisi (Root, 1934) predominated with 113 specimens $(89.7 \%)$. The remaining captured species were Lutzomyia (Pintomyia) mamedei Oliveira, Afonso, Dias \& Brazil, 1994 - five specimens (3.9\%); Lutzomyia (Nyssomyia) flaviscutellata (Mangabeira, 1942) - four specimens (3.2\%); Lutzomyia lenti (Mangabeira, 1938) - two specimens (1.6\%); Brumptomyia avellari (Costa Lima, 1932) - one specimen (0.8\%); and Lutzomyia (Nyssomyia) whitmani (Antunes \& Coutinho, 1939) - one specimen (0.8\%). The collection of species that may be involved in the transmission of Leishmania reveals the need for continuous entomological surveillance.
\end{abstract}

KEYWORDS: Lutzomyia; Phlebotomine; Leishmaniasis; Ecology of vectors.

\section{INTRODUCTION}

Leishmaniasis are manifested in several diseases that afflict humans and that are caused by different species of Trypanosomatidae. A significant increase in these diseases has recently been registered in peri-urban and urban areas of large cities, particularly in Brazil ${ }^{9}$.

In the New World, several phlebotomine species (Diptera: Psychodidae) are involved in the transmission of leishmaniasis. Some of them, which were previously found only in their natural environment, are now frequently found near human dwellings, in banana plantations and in domestic animal shelters, demonstrating that they are adaptating to anthropic modifications ${ }^{20}$. Knowledge about local phlebotomine fauna composition and the behavior of sandfly species helps shed light on several aspects involved in the transmission of leishmaniasis and has been the focus of several investigations $s^{5,19,21}$.

During the period from 2005 to June 2010, the National Database on Reportable Diseases website (http://dtr2004.saude.gov.br/sinanweb/) reported 10 cases of American cutaneous leishmaniasis (ACL) from rural areas that were related to fishing activities, but only a single case of autochthonous human ACL was confirmed in this period. On the other hand, in 2008, a child was diagnosed with visceral leishmaniasis (VL), and subsequent epidemiological studies showed the autochthony of the case as well as the first record of the vector, Lutzomyia longipalpis, in the municipality ${ }^{17}$.
The Parque do Sabiá complex was created with the main purpose of providing less privileged citizens a space for sports and other leisure activities. The complex comprises several ecotopes that favor the presence of sandflies. Moreover, it is close to two neighborhoods in the city where specimens of Lutzomyia longipalpis (Lutz \& Neiva, 1912), a vector incriminated in the transmission of visceral leishmaniasis (VL), have been found and two cases of human VL have been recorded, showing that VL is an important public health problem in the municipality ${ }^{17}$. The objective of this study was to survey the sandfly fauna in the Parque do Sabiá complex and to evaluate the risk of transmission of leishmaniasis.

\section{MATERIAL AND METHODS}

Study area: Located in the eastern sector of the municipality of Uberlândia, Minas Gerais State, Brazil, the Parque do Sabiá complex comprises an area of 1,850,000 $\mathrm{m}^{2}$ with $350,000 \mathrm{~m}^{2}$ of woodlands and three springs that supply seven reservoirs, one large and seven smaller lakes (Fig. 1). It also has a 300-meter-long artificial beach, a zoo with dozens of native and exotic animal species, a fish farm, a 1,080 $\mathrm{m}^{2}$ pavilion housing aquariums and 36 fish species of economic and ornamental value, a 5,100 $\mathrm{m}$ walking track and several resting spaces.

Entomological captures: A total of eight annual sandfly collections, between April 2003 and May 2009 were carried out in the woods along the walking track, using a Shannon trap exposed from 6 p.m. to midnight for three consecutive days. Simultaneously, three CDC traps were set up,

(1) Centro de Controle de Zoonoses, Uberlândia, MG, Brazil.

(2) Laboratório de Leishmanioses, Centro de Pesquisas René Rachou-Fiocruz, Belo Horizonte, MG, Brazil.

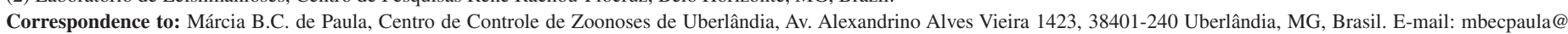
yahoo.com.br 

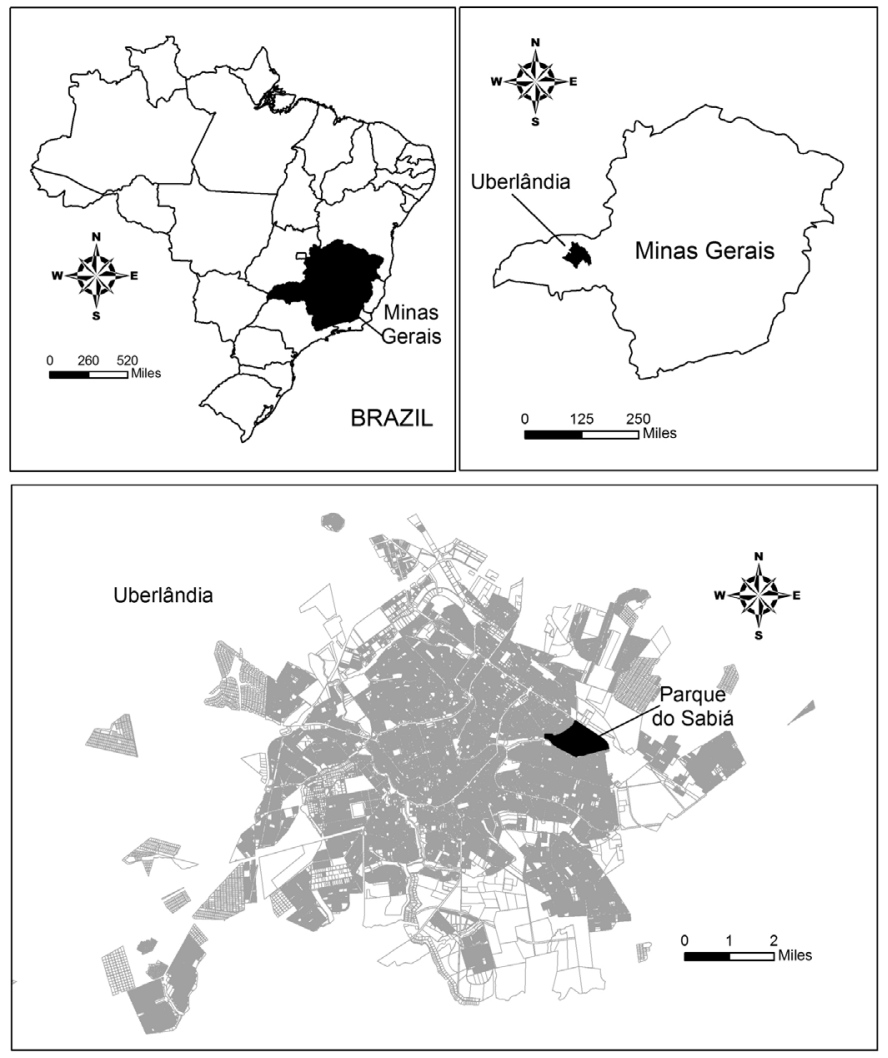

Fig. 1 - Map of Parque do Sabiá, Uberlândia, Minas Gerais State, Brazil. one in the dog kennel of the military police station, one in the zoo (near the monkey cage), and one in the fish farm, these sites were chosen due to their proximity to the walking track used by the public. The collected insects were taken to the Laboratório de Entomologia at the Centro de Controle de Zoonozes (CCZ) of Uberlândia Municipal City Hall (PMU), where they were separated, processed, immersed in Berlese's fluid and mounted in microscope slides and coverslips. They were then identified according to the classification by YOUNG \& DUNCAN (1994) ${ }^{24}$.

\section{RESULTS}

One hundred and twenty-nine specimens of phlebotomines were captured, comprising 95 females (73.6\%) and 34 males (26.4\%). From the total of females, $78(60.5 \%)$ were captured using Shannon trap and $17(13.2 \%)$ with CDC traps. From the total of males, 26 (20.2\%) were captured using Shannon trap and eight (6.2\%) were captured with CDC traps (Table 1). Six species belonging to two genera were identified: Lutzomyia and Brumptomyia (Table 2). The genus Lutzomyia presented three subgenera (Psychodopygus, Nyssomyia and Pintomyia) and one species of the migonei group. Five species of the genus Lutzomyia were identified: Lutzomyia (Psychodopygus) davisi (Root, 1934) predominated (89.7\%), followed by Lutzomyia (Pintomyia) mamedei Oliveira, Afonso, Dias \& Brazil, 1994 (3.9\%), Lutzomyia (Nyssomyia) flaviscutellata (Mangabeira, 1942) (3.2\%), Lutzomyia lenti (Mangabeira, 1938) (1.6\%), and Lutzomyia (Nyssomyia) whitmani (Antunes \& Coutinho, 1939) $(0.8 \%)$. The genus Brumptomyia was represented by Brumptomyia avellari (Costa Lima, 1932) with $0.8 \%$ of the total of sandflies collected, $L .(P$.) davisi was still the most captured specie in both type of traps: Shannon $(84.6 \%)$ and CDC (100\%). Three specimens that were damaged could not be identified and were therefore excluded from the analysis.

Table 1

Sandfly species captured in Parque do Sabiá, Uberlândia, MG, Brazil between April 2003 and May 2009, according to type of trap

\begin{tabular}{|c|c|c|c|c|c|c|c|c|c|}
\hline \multirow{2}{*}{$\begin{array}{l}\text { Number of } \\
\text { capture }\end{array}$} & \multirow[t]{2}{*}{ Month/year } & \multirow[t]{2}{*}{ Species } & \multicolumn{2}{|c|}{ Shannon } & \multirow{2}{*}{$\begin{array}{c}\text { Total } \\
\text { Shannon }\end{array}$} & \multicolumn{2}{|c|}{$\mathrm{CDC}$} & \multirow[t]{2}{*}{ Total CDC } & \multirow[t]{2}{*}{ Total } \\
\hline & & & Males & Females & & Males & Females & & \\
\hline \multirow[t]{2}{*}{1} & $04 / 2003$ & L. (P.) davisi & 9 & 25 & 34 & 8 & 17 & 25 & 59 \\
\hline & & L. sp & - & 1 & 1 & - & - & 0 & 1 \\
\hline 2 & 09/2004 & - & - & - & 0 & - & - & 0 & 0 \\
\hline \multirow[t]{2}{*}{3} & $05 / 2005$ & L. (P.) davisi & - & 6 & 6 & - & - & 0 & 6 \\
\hline & & Brumptomyia avellari & 1 & - & 1 & - & - & 0 & 1 \\
\hline 4 & $09 / 2005$ & L.(N.) flaviscutellata & - & 2 & 2 & - & - & 0 & 2 \\
\hline \multirow[t]{3}{*}{5} & $08 / 2006$ & L. (P.) mamedei & - & 3 & 3 & - & - & 0 & 3 \\
\hline & & L. (N.) whitmani & 1 & - & 1 & - & - & 0 & 1 \\
\hline & & L. sp & - & 1 & 1 & - & - & 0 & 1 \\
\hline \multirow[t]{4}{*}{6} & 09/2007 & L. (N.) flaviscutellata & - & 2 & 2 & - & - & 0 & 2 \\
\hline & & L.(P.) mamedei & - & 1 & 1 & - & - & 0 & 1 \\
\hline & & L. sp & - & 1 & 1 & - & - & 0 & 1 \\
\hline & & L. lenti & 1 & 1 & 2 & - & - & 0 & 2 \\
\hline 7 & $08 / 2008$ & - & - & - & 0 & - & - & 0 & 0 \\
\hline \multirow[t]{2}{*}{8} & 04/2009 & L. (P.) davisi & 14 & 34 & 48 & - & - & 0 & 48 \\
\hline & & L.(P.) mamedei & - & 1 & 1 & - & - & 0 & 1 \\
\hline Total & & & 26 & 78 & 104 & 8 & 17 & 25 & 129 \\
\hline
\end{tabular}


RODRIGUES, E.A.S.; ANDRADE FILHO, J.D.; LIMONGI, J.E. \& PAULA, M.B.C. - Sandfly fauna (DIPTERA: PSYCHODIDAE) in Parque do Sabiá complex, Uberlândia, Minas Gerais, Brazil. Rev. Inst. Med. Trop. Sao Paulo, 53(5): 255-8, 2011.

Table 2

Frequencies, by sex and type of trapping of the sandfly species captured in Parque do Sabiá, Uberlândia, MG, Brazil between April 2003 and May 2009

\begin{tabular}{|c|c|c|c|c|c|c|c|}
\hline \multirow[t]{2}{*}{ Species } & \multicolumn{3}{|c|}{ Shannon } & \multicolumn{3}{|c|}{$\mathrm{CDC}$} & \multirow{2}{*}{$\begin{array}{c}\text { Total of speci- } \\
\text { mens }(\%)\end{array}$} \\
\hline & Males (\%) & Females $(\%)$ & Total $(\%)$ & Males (\%) & Females $(\%)$ & Total $(\%)$ & \\
\hline L. (P.) davisi & $23(18.3)$ & $65(51.6)$ & $88(69.9)$ & $8(6.3)$ & $17(13.5)$ & $25(19.8)$ & $113(89.7)$ \\
\hline L. (P.) mamedei & - & $5(3.9)$ & $5(3.9)$ & - & - & - & $5(3.9)$ \\
\hline L. (N.) flaviscutellata & - & $4(3.2)$ & $4(3.2)$ & - & - & - & $4(3.2)$ \\
\hline L. lenti & $1(0.8)$ & $1(0.8)$ & $2(1.6)$ & - & - & - & $2(1.6)$ \\
\hline Brumptomyia avellari & $1(0.8)$ & - & $1(0.8)$ & - & - & - & $1(0.8)$ \\
\hline L. (N.) whitmani & $1(0.8)$ & - & $1(0.8)$ & - & - & - & $1(0.8)$ \\
\hline Total & $26(20.7)$ & $75(59.5)$ & $101(80.2)$ & $8(6.3)$ & $17(13.5)$ & $25(19.8)$ & $126(100)$ \\
\hline
\end{tabular}

\section{DISCUSSION}

The 129 sandflies captured in this study provided a picture of the phlebotomine fauna in the Parque do Sabiá complex, one of the only and largest public leisure spaces in the city of Uberlândia, and indicated that some of the captured species are involved in the transmission of Leishmania. Our study showed a predominance of females, which is not a new finding and can be explained by the attraction to light and the availability of bloodmeal source close to the traps ${ }^{12}$.

Four specimens of $L$. (N.) flaviscutellata were captured. The attraction of this phlebotomine to rodents places it in contact with the main reservoirs of Leishmania (L.) amazonensi ${ }^{17}$, which is one of the reasons for suggesting it as a vector of this leishmania ${ }^{18}$. This species is not very anthropophilic, and despite its wide geographical distribution and studies that suggest an alteration in the epidemiological profile of cutaneous leishmaniasis by $L$. (L.) amazonensis ${ }^{17}$, evidence of its vectorial role in the study area was not observed.

The specie $L$. (P.) mamedei, of which five specimens were captured in this study, is characterized for its obligatory parthenogenetic females, and hence, the absence of a morphological description of males ${ }^{4}$. Moreover, this species, as well as B. avellari and L. lenti, which were also captured in this study, have not yet been incriminated in the transmission of leishmaniasis ${ }^{3,16}$.

According to CASTELLÓN et al. (1994), among the species of the subgenus Psychodopygus, L. (P.) davisi, the most numerous one in our study, is considered the one with the strongest anthropophilic tendency ${ }^{7}$. This species is usually trapped at ground level ${ }^{1}$, a fact that CHANIOTIS et $a l{ }^{8}$ propose as one of the criteria for incriminating phlebotomine species as potential vectors of leishmania for humans, as well as their population density correlated with their circadian rhythm and with seasonality. On the other hand, the fact that this species was highly abundant in the Shannon trap located in primary woods surroundings contradicts previous researches which reported the presence of animals in the peridomicile providing support to the colonization of this species ${ }^{22,23}$. In this study area, this species still remains closer to the primary woods. This species has already been incriminated as a probable vector of Leishmania (Viannia) naiffi, which causes cutaneous leishmaniasis in the Amazon region ${ }^{10,13}$.

L. (N.) whitmani, which is incriminated as one of the vectors of Leishmania (Viannia) braziliensis, the most prevalent parasite infecting humans and one of the main species involved in American cutaneous leishmaniasis (ACL) in Brazil, is also associated with the presence of domestic animals ${ }^{6,11,13}$. Studies carried out in areas of ACL transmission in Minas Gerais have found $L$. $(N$.) whitmani displaying great behavioral flexibility, anthropophilic activity in surrounding woods and around human dwellings, where it may be developing hematophagous habits involving humans and domestic animals ${ }^{14,17}$. As for seasonality, more systematic studies in southeastern Brazil have demonstrated that this species may be present throughout the year ${ }^{2}$.

In the southeastern region of the Minas Gerais State, known as the Triângulo Mineiro, 14 cases of human ACL coming from the municipalities of Carmo do Paranaíba, Patos de Minas and São Francisco de Sales were reported from 1981 to 1986 . Later, from July to November 1987, 25 patients were diagnosed with ACL, 19 of them living in Uberlândia. The pattern of transmission was considered peridomiciliary, but all the patients' homes were located on the banks of the Araguari river, which they frequented for work, sports and leisure activities, suggesting that the outbreak was of sylvatic origin ${ }^{15}$.

Later studies of the phlebotomine fauna conducted in that region by LEMOS \& LIMA (2005) revealed the presence of only one specimen of $L$. $\left(N\right.$.) whitmani in a total of 6,551 captured phlebotomines ${ }^{14}$. Since the aforementioned period, no other ACL outbreak or epidemic have been registered in the municipality.

Although the focus of the human ACL epidemic registered in the municipality was related to a rural environment, the presence of even a small number of $L$. $(N$.) whitmani is a fact that should keep the health authorities on the alert, since it indicates a risk for the appearance of ACL in this ecotope. In addition, the number of users of this park has been increasing significantly, especially as a result of recent improvements that have been implemented, such as reforestation and environmental control to ensure the preservation of green areas and the headwaters, making it necessary to keep the park under continuous entomological surveillance.

\section{RESUMO}

\section{Flebotomíneos (DIPTERA: PSYCHODIDAE) no complexo Parque do Sabiá, Uberlândia, Minas Gerais, Brasil}

Entre abril de 2003 e maio de 2009, realizaram-se capturas de flebotomíneos no complexo Parque do Sabiá, município de Uberlândia, 
RODRIGUES, E.A.S.; ANDRADE FILHO, J.D.; LIMONGI, J.E. \& PAULA, M.B.C. - Sandfly fauna (DIPTERA: PSYCHODIDAE) in Parque do Sabiá complex, Uberlândia, Minas Gerais, Brazil. Rev. Inst. Med. Trop. Sao Paulo, 53(5): 255-8, 2011.

estado de Minas Gerais, utilizando-se armadilhas CDC e de Shannon. O objetivo foi associar as espécies encontradas ao risco de transmissão de leishmanioses no município. Foram capturados 126 exemplares, distribuídos em seis espécies de flebotomíneos. Houve predomínio de Lutzomyia (Psychodopygus) davisi (Root, 1934) com 113 espécimes (89,7\%). As demais espécies capturadas foram Lutzomyia (Pintomyia) mamedei (Oliveira, Afonso, Dias \& Brazil, 1994) - cinco espécimes (3,9\%); Lutzomyia (Nyssomyia) flaviscutellata (Mangabeira, 1942) quatro espécimes (3,2\%); Lutzomyia lenti (Mangabeira, 1938) - dois espécimes (1,6\%); Brumptomyia avellari (Costa Lima, 1932) - um espécime $(0,8 \%)$ e Lutzomyia (Nyssomyia) whitmani (Antunes \& Coutinho, 1939) - um espécime $(0,8 \%)$. A captura de espécies que podem estar envolvidas na veiculação de Leishmania revela a necessidade de uma vigilância entomológica constante.

\section{ACKNOWLEDGMENTS}

We are indebted to Iram Martins Costa for drawing the maps, to Mauro Santos Lima, Jovenil Gomes da Silva, Wilson Gomes Moreira and Eliana Cristina dos Santos for carrying out the trapping campaigns, and to Vinicius Cardoso de Paula for writing the Abstract.

\section{AUTHOR CONTRIBUTIONS}

Elisângela de Azevedo Silva Rodrigues: conception and design of the study, collection, assembly, analysis and interpretation of data and drafting of the article.

José Dilermando Andrade Filho: analysis and interpretation of data, drafting of the article and critical revision of the article for important intellectual content.

Jean Ezequiel Limongi: analysis and interpretation of data and drafting of the article.

Márcia Beatriz Cardoso de Paula: conception and design of the study, collection, assembly, analysis and interpretation of data and drafting of the article.

\section{REFERENCES}

1. Aguiar GM, Schuback PD, Vilela ML, Azevedo ACR. Aspectos da ecologia dos flebótomos do Parque Nacional da Serra dos Órgãos, estado do Rio de Janeiro. II. Distribuição vertical (Diptera, Psychodidae, Phlebotominae). Mem Inst Oswaldo Cruz. 1985;80:187-94.

2. Barretto MP. Observações sobre a biologia em condições naturais dos flebótomos do Estado de São Paulo (Diptera Psychodidae). São Paulo: Tipografia Rossolillo; 1943.

3. Brazil RP, Carneiro VL, Andrade Filho JD, Alves JCM, Falcão AL. Biology of Lutzomyia lenti (Mangabeira) (Diptera: Psychodidae). An Soc Entomol Brasil. 1997;26:191-93.

4. Brazil RP, Oliveira SMP. Parthenogenesis in sandfly Lutzomyia mamedei (Diptera: Psychodidae). Med Vet Entomol. 1999;13:463-4

5. Cabanillas MRS, Castellon EG. Distribution of sandflies (Diptera: Psychodidae) on tree-trunks in a non-flooded area of the Ducke Forest Reserve, Manaus, AM, Brazil. Mem Inst Oswaldo Cruz. 1999;94:289-96.

6. Cardoso PG, Souza MB, Sanavria A, Meira AM, Meródio JC. Flebótomos de áreas com ocorrências de casos humanos de leishmaniose tegumentar americana no Município de Seropédica, Estado do Rio de Janeiro. Rev Soc Bras Med Trop. 2009;42:146-50.

7. Castellón EG, Arias JR, Freitas RA, Naiff RD. Os flebotomíneos da região Amazônica, estrada Manaus Humaitá, estado do Amazonas, Brasil (Diptera: Psychodidae; Phlebotominae). Acta Amaz. 1994;24:91-102.
8. Chaniotis BN, Correa MA, Tesh RB, Jonhson KM. Daily and seasonal man-biting activity of Phlebotomine sandflies in Panama. J Med Entomol. 1971;8:415-20.

9. Departamento de Vigilância Epidemiológica. Manual de vigilância e controle da leishmaniose visceral. Brasília: Ministério da Saúde; 2006.

10. Feitosa MAC, Castellón EG. Fauna de flebotomíneos (Diptera: Psychodidae) em fragmentos de floresta ao redor de conjuntos habitacionais na cidade de Manaus, Amazonas, Brasil. I. Estratificação vertical. Acta Amaz. 2006;36:539-48.

11. Galati EAB, Nunes VL, Cristaldo G, Rocha HC. Aspectos do comportamento da fauna flebotomínea (Diptera: Psychodidae) em foco de leishmaniose visceral e tegumentar na Serra da Bodoquena e área adjacente, Estado de Mato Grosso do Sul, Brasil. Rev Patol Trop. 2003;32:235-61.

12. Gomes AC, Galati EAB. Aspectos ecológicos da leishmaniose tegumentar americana Estratificação da atividade espacial e estacional de Phlebotominae (Diptera, Psychodidae) em áreas de cultura agrícola da região do Vale do Ribeira, Estado de São Paulo, Brasil. Mem Inst Oswaldo Cruz. 1987;82:467-73.

13. Gontijo B, Carvalho MLR. Leishmaniose tegumentar americana. Rev Soc Bras Med Trop. 2003;36:71-80

14. Lemos JC, Lima SC. Leishmaniose tegumentar americana: flebotomíneos em área de transmissão no município de Uberlândia, MG. Rev Soc Bras Med Trop. 2005;38:22-6.

15. Machado MI, Nishioka SA, Ferreira MS, Costa-Cruz JM, Rocha A, Silva AM, et al. Leishmaniose tegumentar americana no Triângulo Mineiro e Alto Paranaíba, Minas Gerais, Brasil: aspectos clínico-laboratoriais e epidemiológicos de uma microepidemia. Rev Cent Ciênc Bioméd Univ Fed Uberlândia. 1992;8:17-28.

16. Mangabeira Filho O. $8^{\text {a }}$ contribuição ao estudo dos Flebotomus (DIPTERA (PSYCHODIDAE). Flebotomus (Brumptomyia) avellari Costa Lima, 1932. Mem Inst Oswaldo Cruz. 1942;37:225-40.

17. Paula MBC, Rodrigues EAS, Souza AA, Reis AA, Paula FP, Pajuaba Neto AA, et al Primeiro encontro de Lutzomyia longipalpis (Lutz \& Neiva, 1912) na área urbana de Uberlândia, MG, concomitante com o relato de primeiro caso autóctone de leishmaniose visceral humana. Rev Soc Bras Med Trop. 2008;41:304-05.

18. Rangel EF, Lainson R, organizadores. Flebotomíneos do Brasil. Rio de Janeiro: Editora Fiocruz; 2003.

19. Shaw JJ, Lainson R. Leishmaniasis in Brazil. II. Observations on enzootic rodent leishmaniasis in the lower Amazon region - The feeding habits of the vector, Lutzomyia flaviscutellata in reference to man, rodents and the other animals. Trans R Soc Trop Med Hyg. 1968;62:396-405.

20. Souza NA, Andrade-Coelho CA, Vilela ML, Peixoto AA, Rangel EF. Seasonality of Lutzomyia intermedia and Lutzomyia whitmani (Diptera: Psychodidae: Phlebotominae), occurring sympatrically in area of cutaneous leishmaniasis in the State of Rio de Janeiro, Brazil. Mem Inst Oswaldo Cruz. 2002;97:759-65.

21. Tolezano JE, Taniguchi HH, Elias CR, Larosa R. Epidemiologia da leishmaniose tegumentar americana (LTA) no estado de São Paulo. III. Influência da ação antrópica na sucessão vetorial da LTA. Rev Inst Adolfo Lutz. 2001;60:47-51.

22. Ximenes MF, Souza MF, Castellón EG. Density of sandflies (Diptera:Psychodidae) in domestic and wild animal shelters in an area of visceral leishmaniasis in the State of Rio Grande do Norte, Brazil. Mem Inst Oswaldo Cruz. 1999; 94:427-32.

23. Ximenes MF, Silva VP, Queiroz PV, Rego MM, Cortez AM, Batista LM, et al.. Flebotomíneos (Diptera: Psychodidae) e leishmanioses no Rio Grande do Norte, Nordeste do Brasil - Reflexos do ambiente antrópico. Neotrop Entomol. 2007; $36: 128-37$.

24. Young DG, Duncan MA. Guide to the identification and geographic distribution of Lutzomyia sandflies in Mexico, the West Indies, Central and South America (Diptera: Psychodidae). Mem Am Entomol Inst. 1994;54:1-881.

Received: 11 October 2010

Accepted: 30 August 2011 